\title{
Penerapan Framework Codeigniter Pada Pengembangan Website E-Commerce Batik Tulis HR Ambar
}

\author{
Monikka Nur Winnarto ${ }^{1}$, Ita Yulianti ${ }^{2}$, Ami Rahmawati ${ }^{3}$ \\ ${ }^{1,3}$ Sekolah Tinggi Manajemen Informatika dan Komputer Nusa Mandiri \\ e-mail: 114002374@nusamandiri.ac.id, 2ami.amv@nusamandiri.ac.id \\ 2 Universitas Bina Sarana Informatika \\ e-mail: ita.iyi@bsi.ac.id
}

\begin{abstract}
Abstrak
Batik Tulis HR Ambar merupakan badan usaha yang menjual kain dan pakaian batik. Sistem pemasaran dilakukan melalui interaksi secara langsung dengan masyarakat dan sistem penjualan masih secara manual yaitu face to face, hal ini dirasa tidak dapat menjangkau pangsa pasar lebih luas dan tidak dapat meningkatkan jumlah penjualan yang signifikan. Terlebih lagi, di masa pandemi saat ini pembatasan sosial skala besar juga menjadi salah satu kendala dalam melakukan penjualan secara langsung, sehingga keadaan tersebut tentunya menyulitkan pihak Batik Tulis HR Ambar. Oleh karena itu, pembuatan website e-commerce dibutuhkan sebagai salah upaya dalam mengatasi permasalahan yang terjadi pada sistem yang berjalan saat ini. Metode pengumpulan data yang digunakan penelitian ini, meliputi metode observasi, metode wawancara, metode dokumentasi dan metode studi kepustakaan. Selain itu, model waterfall juga diimplementasikan dalam penelitian sebagai metode pengembangan perangkat lunak dalam pembangunan sistem. Dengan dibuatkannya sistem e-commerce pada Batik Tulis HR Ambar, diharapkan dapat memperluas jangkauan pemasaran, mempermudah proses transaksi dan penyampaian informasi kepada konsumen, sehingga dapat meningkatkan penjualan pada Batik Tulis HR Ambar.
\end{abstract}

\section{Kata Kunci : Batik, E-Commerce, Code Igniter}

\begin{abstract}
Batik Tulis HR Ambar is a business entity that sells batik cloth and clothes. The marketing system is carried out through direct interaction with the community and the sales system is still manual, namely face to face, this is considered unable to reach a wider market share and cannot increase the number of significant sales. What's more, in the current pandemic era, large-scale social restrictions have also become one of the obstacles in making direct sales, so this situation certainly makes it difficult for HR Ambar's Batik Tulis. Therefore, making an e-commerce website is needed as an effort to overcome the problems that occur in the current system. The data collection methods used in this study include observation methods, interview methods, documentation methods and literature study methods. In addition, the waterfall model is also implemented in research as a software development method in system development. With the creation of an e-commerce system in Batik Tulis HR Ambar, it is hoped that it can expand the marketing reach, simplify the transaction process and convey information to consumers, so as to increase sales at HR Ambar Batik Tulis.
\end{abstract}

\section{Keywords: Batik, E-Commerce, Code Igniter}

\section{Pendahuluan}

Batik merupakan salah satu hasil kebudayaan Indonesia yang sangat dikagumi bukan hanya karena prosesnya yang rumit tetapi juga dalam motif dan warnanya yang unik dan indah, serta penuh akan makna simbolik (Susanto et al., 2018). Beberapa tahun silam batik memang yang identik dengan pakaian khas orang tua yang cenderung memiliki image kuno dan 
konservatif, namun saat ini batik menjadi produk yang bisa dikonsumsi oleh berbagai kalangan usia (Kurniasih et al., 2018). Tren batik kian memuncak setelah UNESCO menetapkan batik sebagai warisan kemanusiaan untuk lisan dan non bendawi (Masterpiece of the Oral and Intangible Heritage of Humanity) bangsa Indonesia pada tanggal 2 Oktober 2009 (Surya et al., 2017). Kebijakan pemerintahpun turut andil dalam upaya mendorong peningkatan produksi dan pemasaran batik dengan banyaknya industri batik, dimana sentra IKM (Industri Kecil Menengah) batik yang tersebar di wilayah Indonesia terhitung sebanyak 101 sentra dengan 47 ribu unit usaha serta serapan tenaga kerja 200 ribu orang (Utami Agustina Nurie, 2020).

Batik tulis HR Ambar adalah salah satu toko yang bergerak dalam bidang usaha yang menjual kain dan pakaian batik dengan berbagai jenis dan motif batik yang beragam. Usaha ini telah berdiri sejak tahun 2013 dengan persaingan bisnis yang amat ketat. Perkembangan usaha Batik Tulis HR Ambar tidak terlalu signifikan karena usaha ini hanya dikenal oleh masyarakat lokal. Sistem penjualan dan pemasaran pada Batik Tulis HR Ambar masih mengandalkan interaksi dengan konsumen secara langsung dan hanya berpusat di daerah Klaten. Terlebih lagi, di masa pandemi saat ini pembatasan sosial skala besar juga menjadi salah satu kendala dalam melakukan penjualan secara langsung, sehingga hal tersebut tentunya menyulitkan pihak Batik Tulis HR Ambar untuk bisa meningkatkan jumlah penjualan dan memperluas area pemasaran hingga ke luar kota Klaten. Sejauh ini, dengan kondisi ekonomi yang belum begitu baik karena tidak adanya peningkatan penjualan yang signifikan mengharuskan usaha ini untuk mencari terobosan baru dengan cara menjajaki peluang bisnis secara online melalui pemanfaatan website e-commerce.

E-commerce merupakan satu set teknologi, aplikasi dan proses bisnis yang menghubungkan perusahaan dengan pelanggan melalui perdagangan barang dan penyampaian informasi serta pelayanan yang terjadi secara elektronik (Sandy, 2015). Media e-commerce dinilai mampu memenuhi kebutuhan perluasan pemasaran secara efektif dan efisien (Semuel, 2020). Keberadaan e-commerce membuat sebuah perusahaan dapat menjangkau pasar global sekitar $56 \%$, promosi produk $63 \%$, dapat membangun merk produk $56 \%$, dapat menjalin kedekatan hubungan dengan konsumen $74 \%$, mempemudah komunikasi dengan konsumen 63\%, memberikan kepuasan kepada konsumen 56\%, keunggulan bersaing $81 \%$ (Sandy, 2015).

E-commerce menekankan penggunaan teknologi informasi dan komunikasi (TIK) dalam transaksi antara perusahaan dan organisasi, serta antara perusahaan dan konsumen sehingga mampu memudahkan produsen dalam berkomunikasi dengan konsumen dan dalam pengelolaan produk yang dijual (Febriyati et al., 2020). Untuk membangun sebuah website e-commerce dibutuhkan sebuah framework yang mampu menangani pembangunan dan pengembangan website itu sendiri sehingga developer tidak harus membuat website dari awal dan sumberdaya yang dibutuhkan tidak terlalu banyak (R. Maulana \& Rachmawati, 2017). Code igniter merupakan salah satu framework PHP yang kuat yang dibangun bagi para pengembang bahasa pemrograman PHP yang membutuhkan alat untuk membuat web dengan fitur lengkap (Destiningrum \& Adrian, 2017). Kelebihan penggunaan framework ini yaitu bersifat open source, reuse code dan dapat menghemat waktu pengembangan.

Berdasarkan permasalahan yang telah diuraikan pada sistem yang sedang berjalan saat ini, maka dapat disimpulkan bahwa Batik tulis HR Ambar membutuhkan solusi dengan menerapkan teknologi internet sebagai salah satu cara promosi produk dengan menerapkan framework codeigniter pada pengembangan website e-commerce.

\section{Metode Penelitian}

Metode penelitian merupakan suatu cara tentang memahami isi dan permasalahan serta menyelesaikan masalah yang terjadi di dalam sebuah web (AS Muhammad Ali dan \& Noer Azni Septiani, 2016).

\subsection{Teknik Pengumpulan Data}

Teknik pengumpulan data yang digunakan sebagai berikut (S. M. Maulana et al., 2015) :

\section{a. Metode Observasi}

Teknik ini merupakan pengumpulan data dengan cara mengamati dan mengumpulkan data secara langsung terhadap objek yang hendak diteliti. Pengumpulan data dilakukan dengan melakukan observasi langsung di toko Batik Tulis HR Ambar sehingga diperoleh 
data dari berbagai produk yang dijual di toko tersebut.

b. Metode Wawancara

Yaitu teknik pengumpulan data yang dilakukan dengan cara tanya jawab antara dua pihak yaitu pewawancara dan narasumber untuk memperoleh data dan informasi. Pada teknik ini, wawancara dilakukan terhadap owner dan karyawan toko untuk mengetahui sejarah dan profil, produk yang dijual, dan sistem penjualan yang saat ini berjalan.

c. Metode Dokumentasi

Teknik dengan cara pengambilan gambar terhadap objek yang ada di tempat penelitian. Metode dokumentasi ini digunakan untuk memperoleh fotofoto produk yang dijual di Batik Tulis HR Ambar.

d. Metode Studi Kepustakaan

Metode ini dilakukan dengan menelusuri berbagai karya tulis ilmiah mulai dari pembahasan-pembahasan penelitian terdahulu dan referensi ilmiah dengan menggunakan literatur dari buku-buku dan jurnal yang berkaitan dengan objek penelitian.

\subsection{Teknik Pengembangan Sistem}

Adapun metode yang digunakan dalam pengembangan sistem pada penelitian ini yaitu menggunakan model Waterfall yang terbagi kedalam lima tahapan (Safitri \& Supriyadi, 2015) yang dijelaskan dalam uraian berikut:

a. Analisa Persyaratan

Seluruh informasi kebutuhan software harus dapat diperoleh dalam fase ini, termasuk didalamnya kegunaan software yang diharapkan nantinya. Informasi tersebut biasanya dapat diperoleh melalui teknik pengumpulan data untuk kemudian dianalisis agar dapat diperoleh dokumentasi kebutuhan pengguna yang akan digunakan pada tahap selanjutnya.

b. Desain Sistem

Tahapan ini dilakukan sebelum masuk proses pembuatan coding yang bertujuan untuk memberikan gambaran apa yang seharusnya dikerjakan dan bagaimana tampilan yang diinginkan. Dengan adanya tahapan ini dapat membantu memberikan informasi mengenai kebutuhan hardware dan sistem serta mendefinisikan arsitektur sistem secara keseluruhan. c. Implementasi

Dalam tahap ini dilakukan pemrograman. Pembuatan software kemudian diurai menjadi modul-modul kecil yang nantinya akan digabungkan dalam tahapan berikutnya. Selain itu, pemeriksaaan terhadap modul yang dibuat juga dilakukan dengan mempertimbangkan apakah sistem yang dibuat sudah memenuhi fungsi yang diinginkan atau belum.

d. Integrasi dan Testing

Di tahap ini dilakukan penyatuan modulmodul yang sudah dibuat dan pengujian dilakukan untuk mengetahui kendala atau error dan kesesuaian desain yang diharapkan pada sistem yang dibuat.

e. Operasi dan Maintenance

Tahapan ini merupakan tahap terakhir dalam model waterfall. Sistem yang telah selesai kemudian dijalankan dan dilakukan pemeliharaan. Pemeliharaan tersebut termasuk kedalam memperbaiki kesalahan atau error yang tidak ditemukan pada langkah sebelumnya serta perbaikan implementasi unit sistem dan peningkatan jasa sistem sebagai kebutuhan baru.

\section{Hasil dan Pembahasan}

\subsection{Tinjauan Perusahaan}

Batik Tulis HR Ambar adalah sebuah toko yang menjual berbagai produk batik diantaranya kain batik, pakaian batik, seprei batik, mukena batik, taplak meja batik, sarung bantal dan guling batik dengan berbagai motif dan jenis yang beragam . Batik Tulis HR Ambar terletak di Pagerjurang, Bayat, Klaten. Toko ini merupakan bisnis keluarga yang didirikan oleh ibu HR Ambar.

\subsection{Analisa Kebutuhan Sistem}

Spesifikasi dari Sistem Penjualan ( $E$ commerce) pada Batik Tulis HR Ambar terdiri dari 3 Halaman yaitu Halaman Pengunjung, Halaman Pelanggan dan Halaman Admin:

\section{a. Use Case Diagram Pengunjung, Pelanggan, Admin}




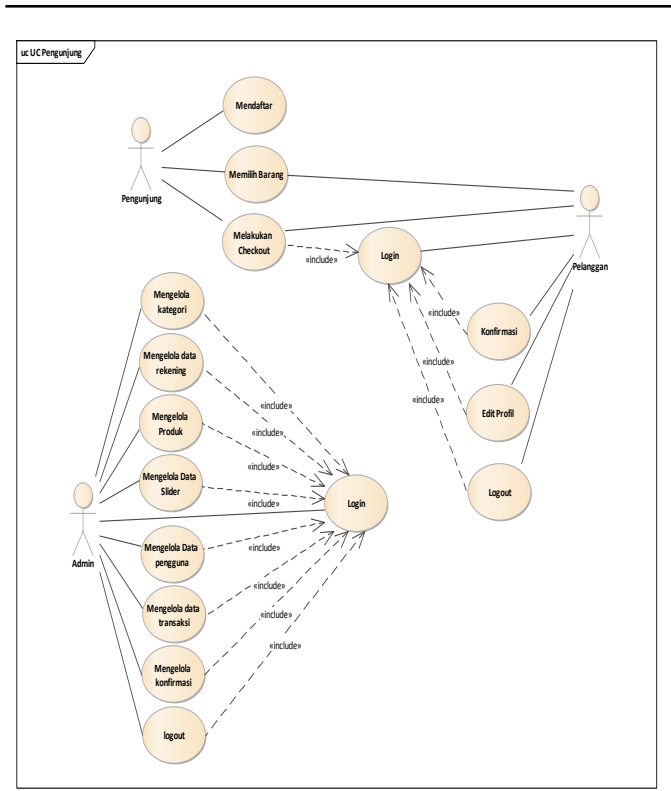

Gambar 1. Use Case Diagram

Pengunjung, Pelanggan, Admin

Pengunjung dapat memilih barang yang ingin dibeli, namun harus melakukan registrasi terlebih dahulu untuk dapat melakukan checkout. Seorang pelanggan dapat login ke halaman pelanggan, dapat memilih barang, melakukan checkout, konfirmasi pembayaran, edit profil dan logout. Admin dapat mengelola data kategori, data produk, data rekening, data slider, melihat transaksi dan mencetak laporan.

\section{b. Activity Diagram}

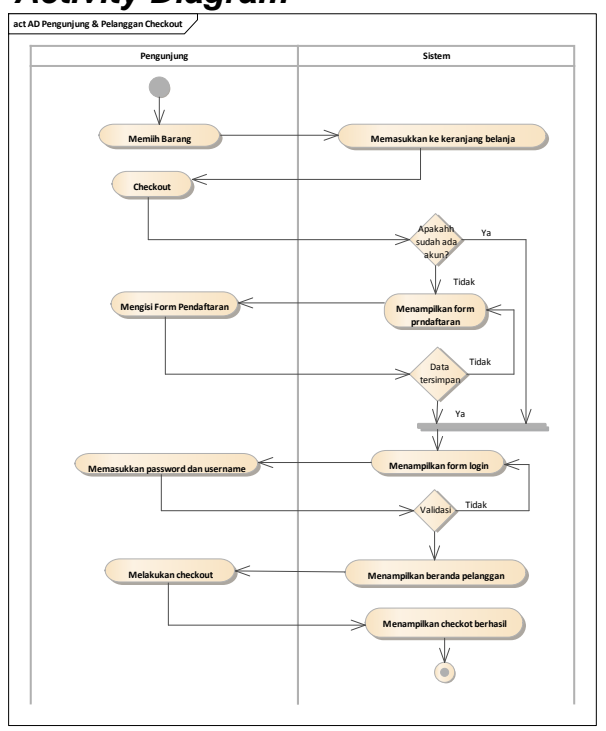

\section{Gambar 2. Activity Diagram Pengunjung \& Pelanggan Memilih dan Checkout Produk}

Pada saat mengakses web, Pelanggan dan pengunjung dapat memilih barang yang ingin dibeli kemudian login terlebih dahulu untuk dapat checkout, apabila belum memilki akun harus registrasi terlebih dahulu.

\section{c. Class Diagram Sistem}

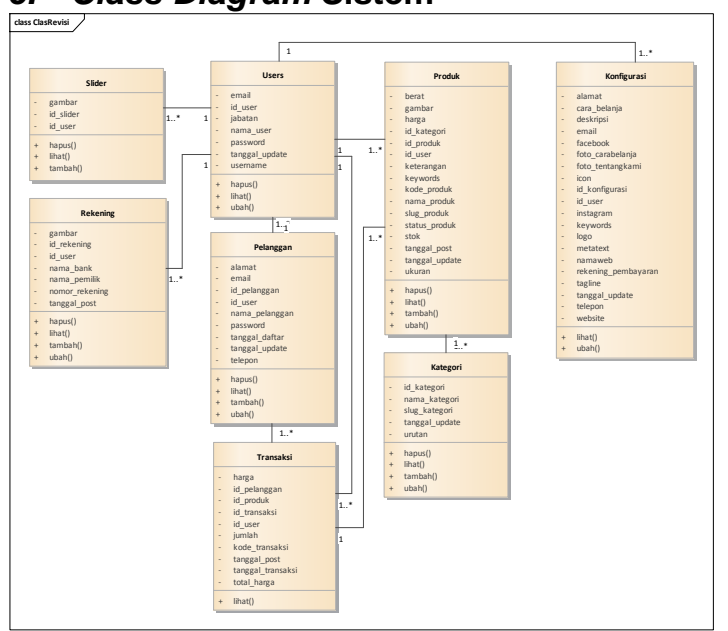

Gambar 3. Class Diagram Sistem

\section{d. Deployment Diagram}

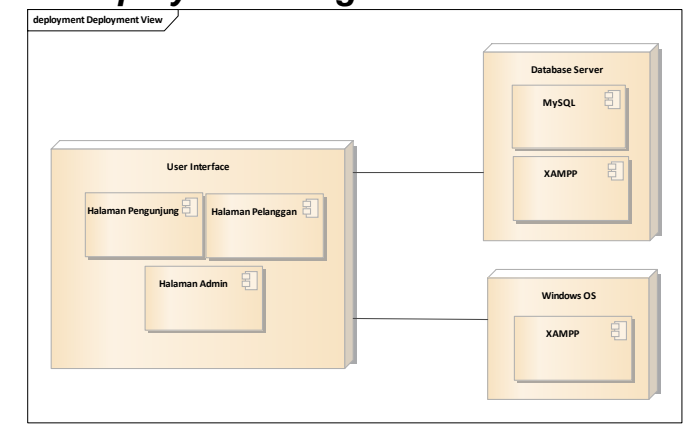

Gambar 4. Deployment Diagram

\section{e. Component Diagram}

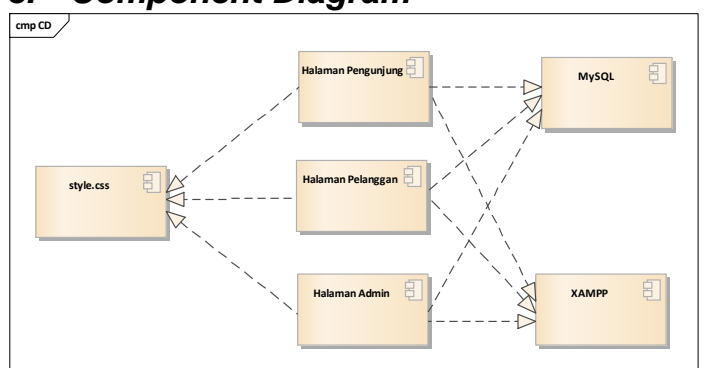

Gambar 5. Component Diagram

\subsection{Rancangan Basis Data}

Dalam pengembangan website $e-$ commerce ini, perancangan basis data dideskripsikan dengan menggunakan Entity Relationship Diagram (ERD) yang disajikan pada gambar berikut: 


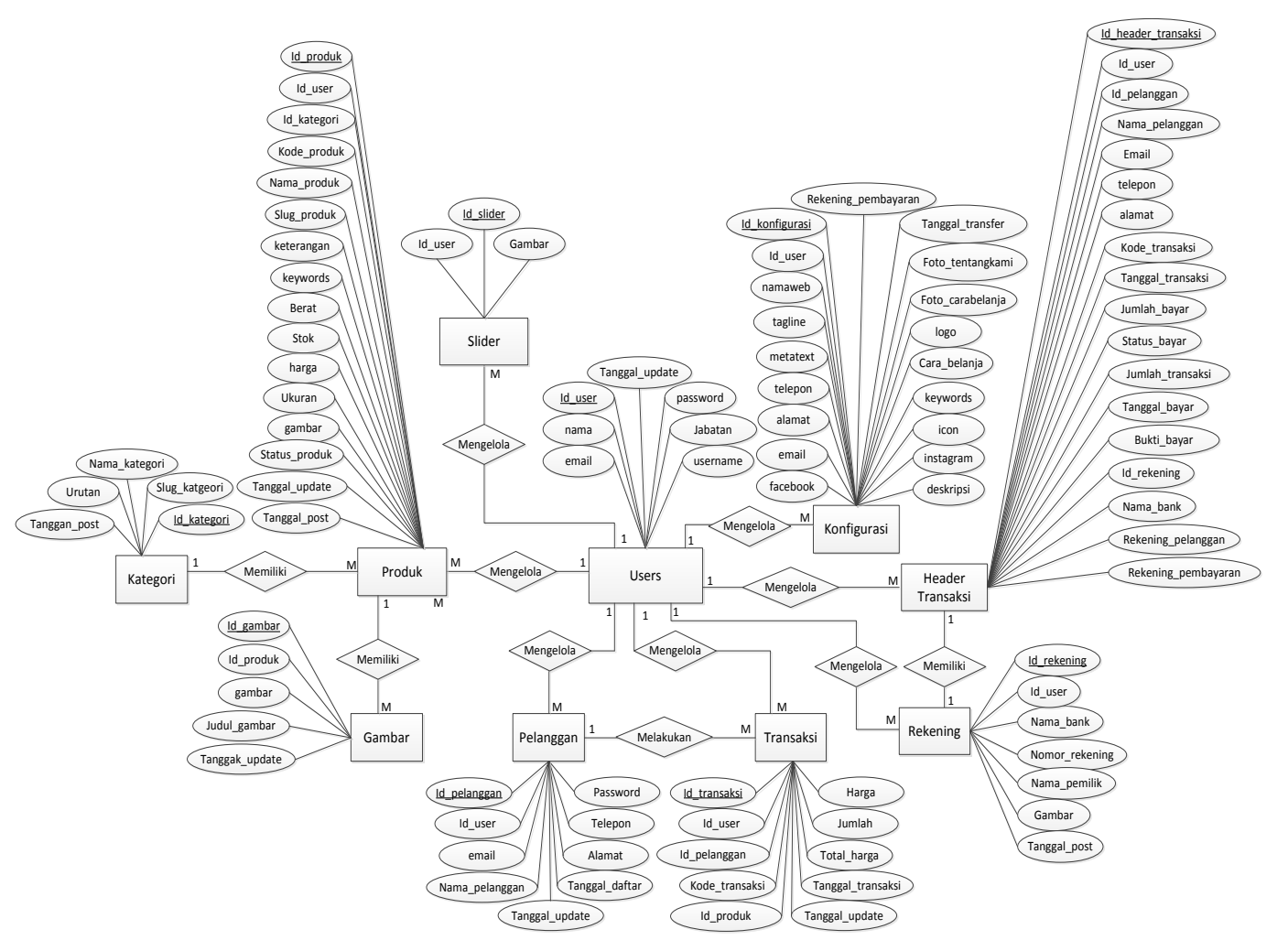

Gambar 6. Entity Relationship Diagram

3.4 Implementasi

\section{A. Halaman Home}

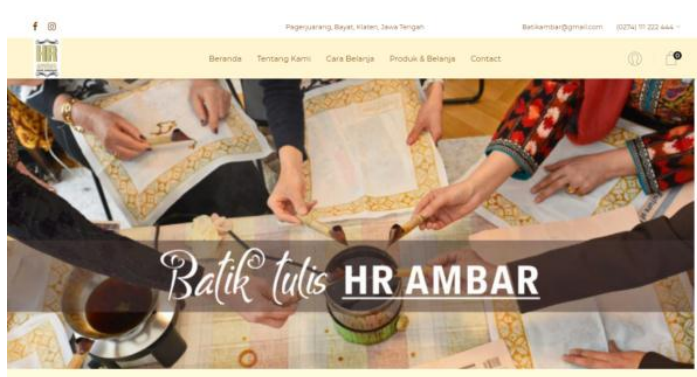

PRODUK TERBARU
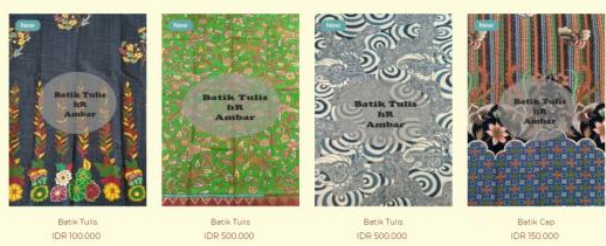

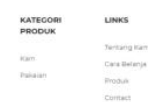

Gambar 7. Halaman Home
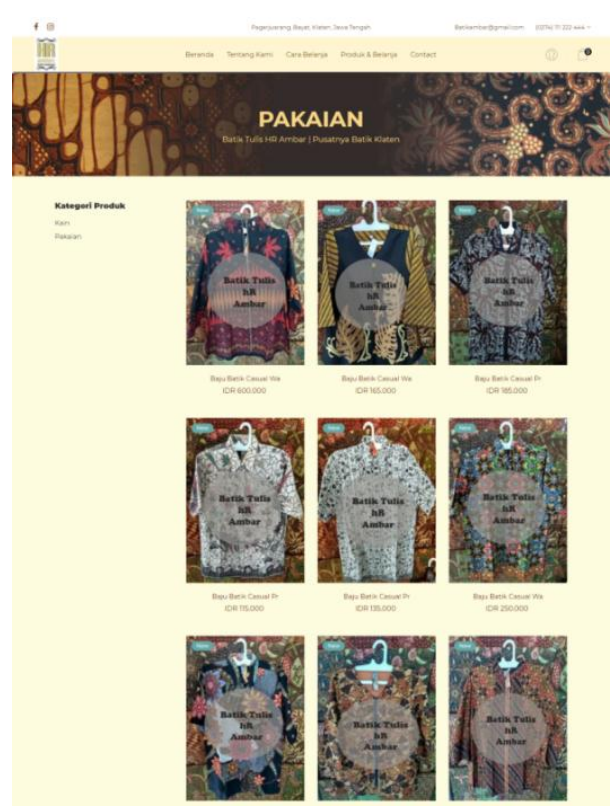

10050000

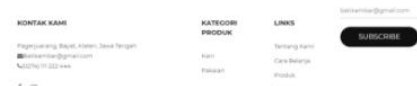

Gambar 8. Halaman Produk 


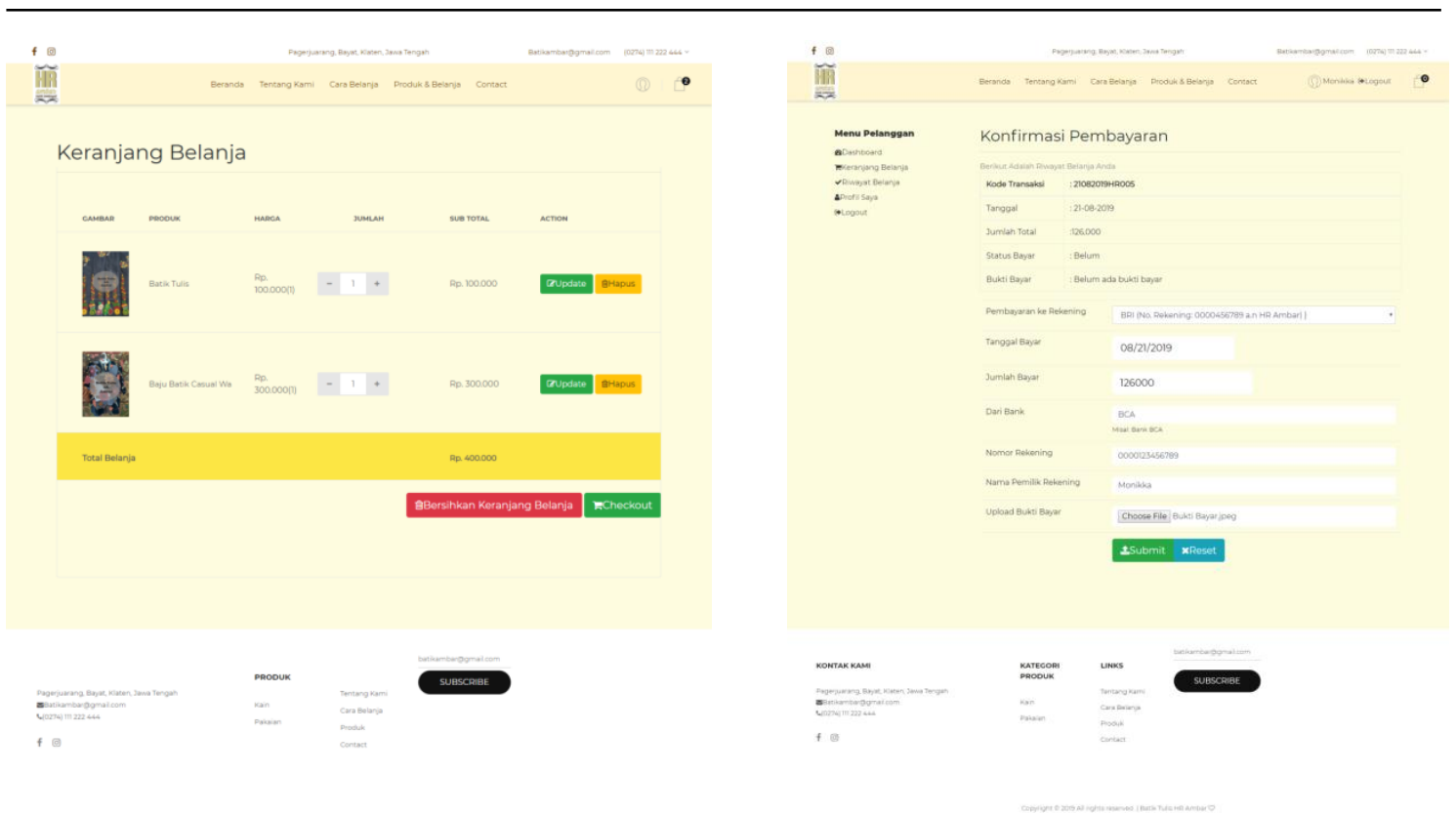

Gambar 9. Halaman Keranjang Belanja

Gambar 11. Halaman Konfirmasi Bayar
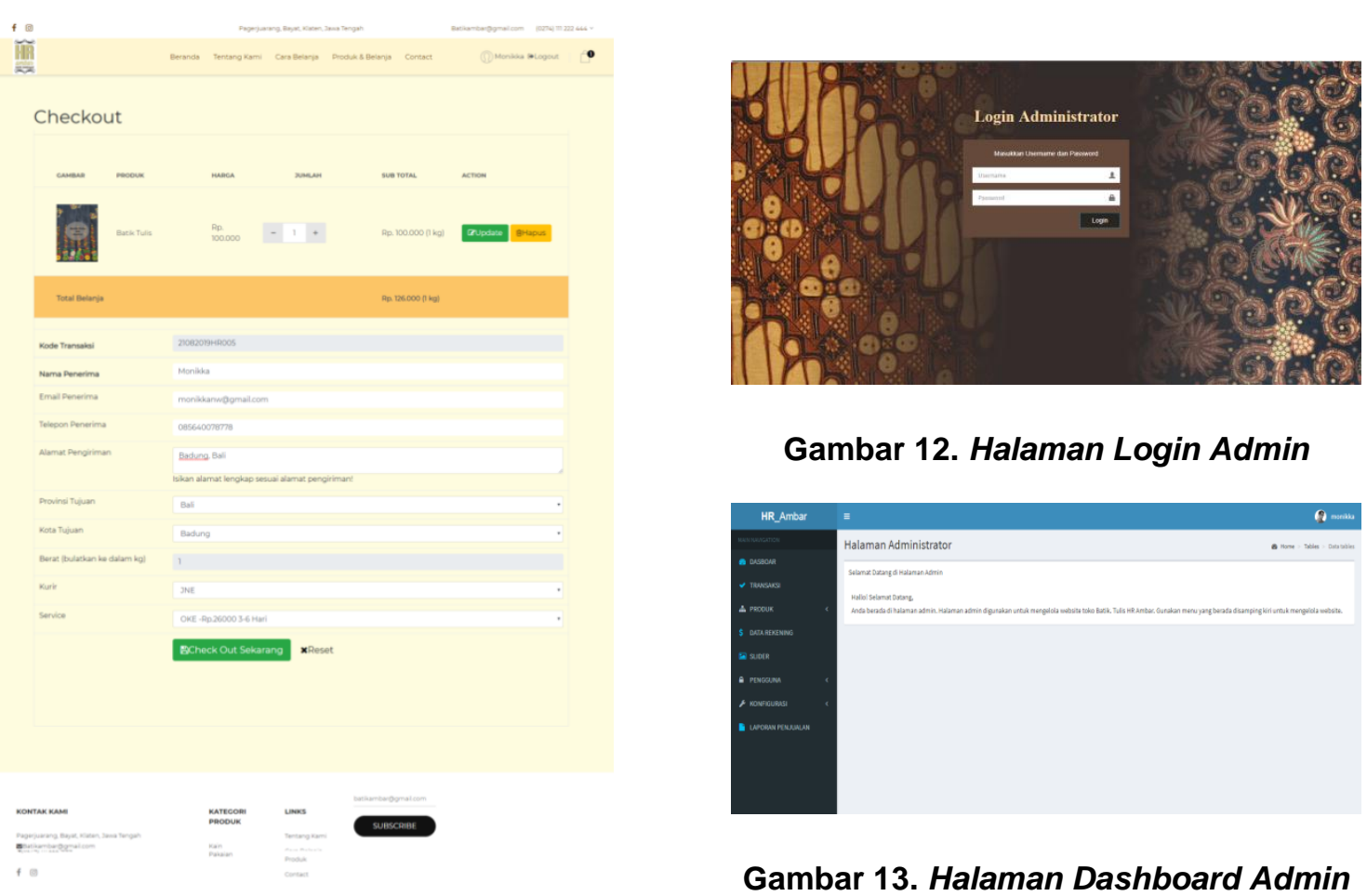

Gambar 12. Halaman Login Admin

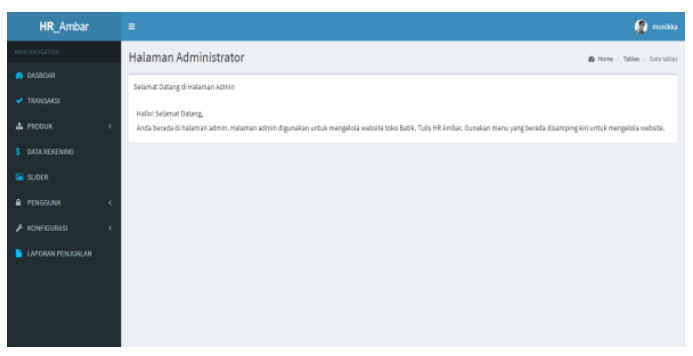

Gambar 13. Halaman Dashboard Admin

Gambar 10. Halaman Checkout 


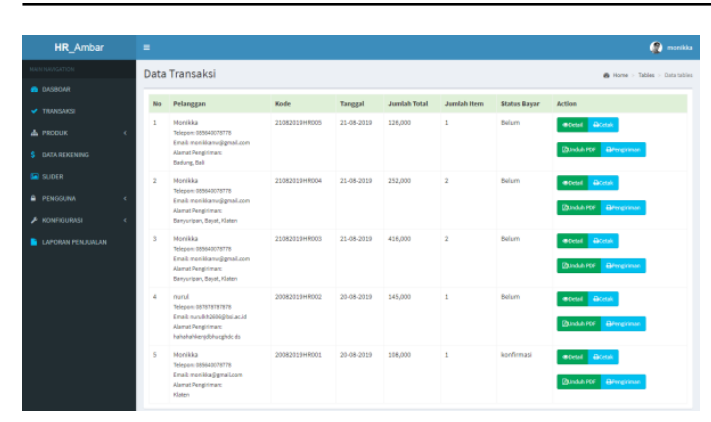

Gambar 14. Halaman Data Transaksi

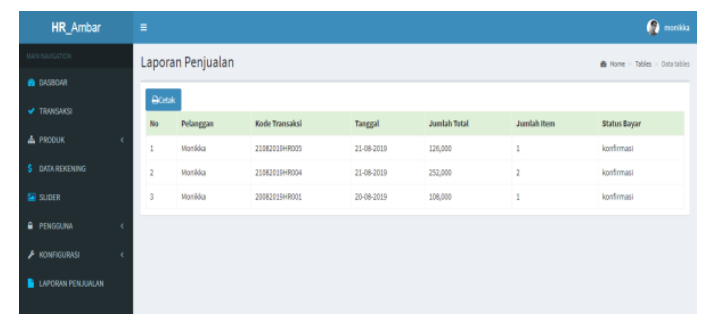

Gambar 15. Halaman Laporan Penjualan

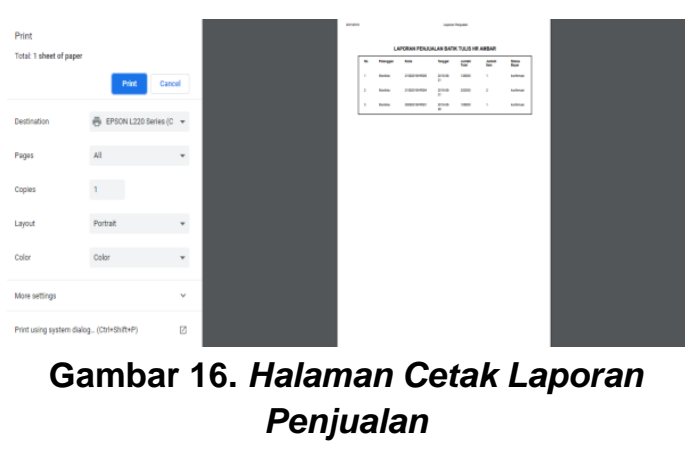

\section{Kesimpulan}

Berdasarkan penjelasan yang telah disampaikan, maka dapat disimpulkan bahwa hasil akhir yang diperoleh dalam penelitian ini yaitu berupa pengembangan website e-commerce pada Batik Tulis HR Ambar sebagai salah satu media promosi yang dapat memperluas area pangsa pasar dan mempermudah penyampaian informasi bagi konsumen.

Dengan adanya website e-commerce tersebut, diharapkan dapat mempermudahkan konsumen dalam melakukan transaksi pembelian yang dapat dilakukan kapanpun dan dimanapun (tanpa harus datang ke toko langsung) sehingga berpotensi dapat meningkatkan jumlah penjualan produk pada toko Batik Tulis HR Ambar. Selain itu, kemudahan dalam pengelolaan proses transaksi dan monitoring bagi karyawan toko dalam sistem ini juga diduga dapat meningkatkan kinerja karyawan dalam memberikan pelayanan prima sehingga kepuasan konsumen dapat tercapai.

\section{Referensi}

AS Muhammad Ali dan, \& Noer Azni Septiani. (2016). PERANCANGAN SISTEM INFORMASI AKADEMIK MENGGUNAKAN METODE WATERFALL Studi Kasus: MADRASAHALIYAH ALMANSYURIYAH KANZA MEKARJAYA TANGERANG. Jurnal Techno Nusa Mandiri, 13(2), 80-88. http://ejournal.nusamandiri.ac.id/ejurn al/index.php/techno/article/view/316

Destiningrum, M., \& Adrian, Q. J. (2017). Sistem Informasi Penjadwalan Dokter Berbassis Web Dengan Menggunakan Framework Codeigniter (Studi Kasus: Rumah Sakit Yukum Medical Centre). Jurnal Teknoinfo, 11(2), 30. https://doi.org/10.33365/jti.v11i2.24

Febriyati, N. A., Arnol, M. Y., Informasi, S., Online, P., \& Nugraha, B. W. (2020). PERANCANGAN SISTEM INFORMASI PENJUALAN ONLINE BERBASIS WEB DESIGN SALES INFORMATION SYSTEM ONLINE BASED ON WEB ON BATIK. 3(3), 153-158. https://doi.org/10.33387/jiko

Kurniasih, R., Wulandari, S. Z., \& Luhita, T. (2018). Minat beli dan karakteristik konsumen batik di banyumas. November, 402-409.

Maulana, R., \& Rachmawati, R. F. (2017). Membangun Website E-Commerce Menggunakan Framework Codeigniter Pada Chemistry Merch. Krea-Tif, 5(2), 86.

https://doi.org/10.32832/kreatif.v5i2.21 88

Maulana, S. M., Susilo, H., \& Riyadi. (2015). Implementasi E-Commerce Sebagai Media Penjualan Online (Studi Kasus Pada Toko Pastbrik Kota Malang). Jurnal Administrasi Bisnis, 29(1), 1-9.

Safitri, S. T., \& Supriyadi, D. (2015). Rancang Bangun Sistem Informasi Praktek Kerja Lapangan Berbasis Web dengan Metode Waterfall. Jurnal Informatika,Telekomunikasi Dan Elektronika, $\quad 7(1), \quad 3-8$. https://doi.org/10.20895/infotel.v7i1.11 1

Sandy, K. (2015). Perancangan Dan Pemanfaatan E-Commerce Untuk Memperluas. Seminar Nasional Teknologi Informasi Dan Komunikasi, 
2015(March 2015), 17-24.

Semuel, H. (2020). Online Consumer Analysis of Indonesian Traditional Batik Products. Jurnal Manajemen Dan Kewirausahaan, 22(1), 11-20. https://doi.org/10.9744/jmk.22.1.11-20

Surya, R. A., Fadlil, A., \& Yudhana, A. (2017). Ekstraksi Ciri Metode Gray Level Co-Occurrence Matrix ( GLCM ) dan Filter Gabor untuk Klasifikasi Citra Batik Pekalongan. Jurnal Informatika:Jurnal Pengembangan IT (JPIT, Vol. 02, No. 02, Juli 2017, 02(02), 23-26.

Susanto, B., Kristen, U., Wacana, D.,
Valgian, B., Kristen, U., Wacana, D., Virginia, G., Kristen, U., Wacana, D., Proboyekti, U., Kristen, U., \& Wacana, D. (2018). Perancangan Awal Model Pengetahuan Batik Indonesia Berbasis Semantic Perancangan Awal Model Pengetahuan Batik Indonesia Berbasis Semantic Web Budi Susanto , Beryl Valgian , Gloria Virginia , Umi Proboyekti. October, 424-433.

Utami Agustina Nurie, T. D. N. (2020). PREFERENSI KONSUMEN TERHADAP PEMBELIAN BATIK TULIS. 1, 260-271. 